
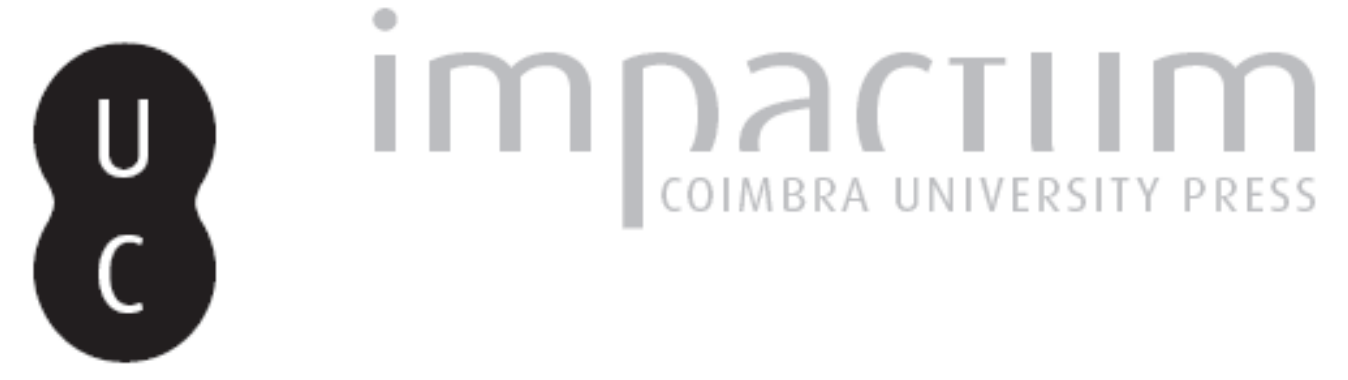

\title{
The political economy of pension systems with lowskilled labor mobility: a crosssscountry analysis
}

\author{
Autor(es): $\quad$ Gouveia, Ana Fontoura
}

Publicado por: Imprensa da Universidade de Coimbra

URL persistente:

URI:http://hdl.handle.net/10316.2/43508

DOI:

DOI:https://doi.org/10.14195/2183-203X_45_2

Accessed : $\quad$ 26-Apr-2023 14:15:18

A navegação consulta e descarregamento dos títulos inseridos nas Bibliotecas Digitais UC Digitalis, UC Pombalina e UC Impactum, pressupõem a aceitação plena e sem reservas dos Termos e Condições de Uso destas Bibliotecas Digitais, disponíveis em https://digitalis.uc.pt/pt-pt/termos.

Conforme exposto nos referidos Termos e Condições de Uso, o descarregamento de títulos de acesso restrito requer uma licença válida de autorização devendo o utilizador aceder ao(s) documento(s) a partir de um endereço de IP da instituição detentora da supramencionada licença.

Ao utilizador é apenas permitido o descarregamento para uso pessoal, pelo que o emprego do(s) título(s) descarregado(s) para outro fim, designadamente comercial, carece de autorização do respetivo autor ou editor da obra.

Na medida em que todas as obras da UC Digitalis se encontram protegidas pelo Código do Direito de Autor e Direitos Conexos e demais legislação aplicável, toda a cópia, parcial ou total, deste documento, nos casos em que é legalmente admitida, deverá conter ou fazer-se acompanhar por este aviso.

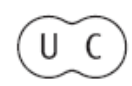




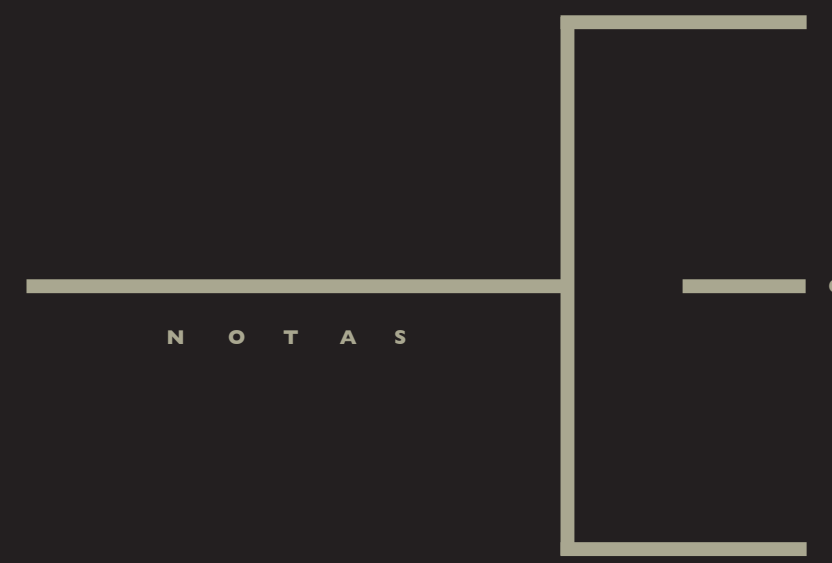

Helder Sebastião / António Portugal Duarte / Gabriel Guerreiro Where is the Information on USD/Bitcoin Hourly Prices?

ANA Fontoura GOUVEIA The Political Economy of Pension Systems with Low-Skilled Labor Mobility:A Cross-Country Analysis

Manuela Magalhães / Ana Paula Africano Panel Analysis of the FDI Impact on International Trade Revisited

Teresa Garcia / Paulo Vieira

O Mercado de Crédito Especializado ao Consumo em Portugal

JoÃo SOUSA ANDRADE As Reformas Monetárias e o Euro 


\title{
The Political Egonomy of Pension Systems with Low-Skilled Labor Mobility: A Gross-Gountry Analysis

\author{
Ana Fontoura Gouveia
}

Received for publication: January 3, 2017

Revision accepted for publication: March 27, 2017

\begin{abstract}
This paper analyzes the impact of international low-skilled labor mobility on the majority support for a pension system in individual countries and on the welfare of the different agents. The two countries considered differ in the amount of redistribution from the high to the low-skilled population embedded in their pay-as-you-go social security systems, whose size (tax rate) is decided by majority voting, anticipating the impact on mobility. We show that labor mobility can create the conditions for a majority to favor pensions in a Bismarckian country, due to the ageing of the population caused by the departure of the young mobile. In a Beveridgean country, mobility does not necessarily undermine the support for the system, but may make the conditions for its existence more stringent, even if no individual migrates in equilibrium. Finally, we show that while labor mobility is always politically sustainable in the non-redistributive country, its political feasibility is at stake in the country performing income redistribution through the pension system whenever the interest rate is not sufficiently large.
\end{abstract}

Keywords: Pension systems; labor mobility; fiscal competition; political economy.

JEL Classification: H55; R23; D72; H73.

Acknowledgement: Part of this research was conducted while the author was visiting the Centre of Research in Public Economics and Population Economics (CREPP), University of Liège and Toulouse School of Economics. The author would like to thank Susana Peralta, Alain Jousten, Pierre Pestieau, Philippe de Donder, Lionel Artige, Sergio Perelman and one anonymous referee for the useful discussions. This research was partially funded by Fundação para a Ciência e Tecnologia. 


\section{INTRODUGTION}

Most pension systems and, more broadly, the welfare systems in European Union countries were introduced in the turn from the 19th to the 20th century and were consolidated in the 1950's, in a context where the integration of markets was just beginning. Today, at the European Union level, free mobility of goods, services, capital and labor is increasingly a reality. Nevertheless, despite the significant achievements so far, the European integration is still hampered by different national regulations, non-harmonized national taxation policies and national welfare systems. ${ }^{1}$ Social security policy decisions remain a national responsibility and the most ambitious EU-wide initiatives entail a great degree of flexibility, like the so-called Open Method of Coordination.

This integration has important implications for national policies. In particular, when designing a national pension system with integrated markets, one must take into account not only the objectives and sustainability of the system (as with non-integrated markets), but also the incentives that the different national designs create in different markets, in particular the factors markets. Standard fiscal competition literature would advise that the relevant market of the tax base should determine the level of government at which the policy is set up. Asymmetric systems, size and redistribution-wise, may therefore impact the allocation of labor and impact the welfare of the agents and of countries in non-expected ways. Two questions then arise: is labor mobility empirically relevant in the EU context? And how different are the EU pension schemes?

On the first question, it is sometimes argued that despite the theoretical free mobility of labor, barriers (like cultural differences, for example) are still dominant. According to European Commission (2013), net migration is the main driver of population growth in the EU. In fact, in 2011 the natural increase of the population contributed to only one-third of the population growth in the EU. In the same year, migrants from other EU countries represented $3.4 \%$ of the EU population, with the situation varying greatly from country to country (migration from countries outside the EU accounted for 6.6\%). The relevance of the mobility of labor within EU countries is, therefore, non-negligible. However, migration entails both pecuniary and non-pecuniary costs (settling costs, being far from home, learning a new language). Thus, mobility induced by different welfare systems (in our case, the pension system) arises only if the potential benefits are significant. Wildasin (1997) estimated the net public pension wealth (negative for net contributors to the system and positive for net beneficiaries) for some EU countries and concluded that, for particular combinations of origin and destination countries, the gains of moving from one country to the other may reach $25 \%$ of lifetime wealth. There is indeed evidence that welfare is one of the factors contributing to labor mobility (see, for instance Meyer, 2000, and Giorgi and Pellizzarib, 2009) and welfare-induced migration has been widely discussed by the public opinion in countries such as the UK or Germany.

On the second question, the European Union is also a good example of asymmetric pension systems. Even if one may speak of an European social model with distinctive features

\footnotetext{
${ }^{1}$ In addition to this, even the single currency or the Schengen convention are not applied uniformly across the European Union.
} 
from the rest of the world (as discussed, for example, in Cousins, 2005: 239-241), we are far from a common European welfare state. The welfare states in the EU remain a national responsibility and, as we will see next, they differ substantially across countries, both in size and in level of redistribution.

In our analysis, we focus on public pensions given "the prominent role of the State in pension provision in the EU countries" (European Commission, 2015).

Table 1 displays the size of public pension systems, measured by the share of expenditure in the GDP. Public pensions have a significant weight on EU economies, surpassing $11 \%$ of GDP for the EU28. And the situation is quite diverse at country level: the country with the highest share (Greece) spends more than twice as much as the country with the lowest share (Netherlands). ${ }^{2}$

Table 1: Public pensions expenditure as a share of GDP in 2013, EU countries

\begin{tabular}{|l|c|l|c|l|c|}
\hline Netherlands & 6.9 & Luxembourg & 9.4 & Slovenia & 11.8 \\
\hline Lithuania & 7.2 & Gyprus & 9.5 & Spain & 11.8 \\
\hline Ireland & 7.4 & Malta & 9.6 & Finland & 12.9 \\
\hline Estonia & 7.6 & Bulgaria & 9.9 & Portugal & 13.8 \\
\hline United Kingdom & 7.7 & Germany & 10.0 & Austria & 13.9 \\
\hline Latvia & 7.7 & Denmark & 10.3 & France & 14.9 \\
\hline Slovakia & 8.1 & Croatia & 10.8 & Italy & 15.7 \\
\hline Romania & 8.2 & Poland & 11.3 & Greece & 16.2 \\
\hline Sweden & 8.9 & Hungary & 11.5 & EU28 & 11.3 \\
\hline Czech Republic & 9.0 & Belgium & 11.8 & Euro Area & 12.3 \\
\hline
\end{tabular}

Source: European Commission (2015).

There are also important differences across countries regarding the redistributive nature of the public pension systems. A fully Beveridgean system provides a flat rate pension, whereas a fully Bismarckian system is purely earnings-related. In the EU, "in a few Member States, notably in Denmark, the Netherlands, Ireland and the United Kingdom, the public pension system provides in the first instance a flat-rate pension, which can be supplemented by earnings-related private occupational pension schemes (in the UK, also by a public earnings-related pension scheme State Second Pension and in Ireland by an earnings-related pension scheme for public service employees)" . ${ }^{3}$ Table 2 shows that only five countries allow for the same replacement ratios for high and low earners (namely Germany, Hungary, Italy, Poland and Spain). In all the other countries presented, low earners have

\footnotetext{
${ }^{2}$ It should be noted that pensions are not only provided through public systems and thus the inclusion of private pension schemes, which are significant in some countries, may give a different picture.

${ }^{3}$ European Commission (2015).
} 
higher replacement ratios. In countries such as Ireland and Denmark the difference is as high as 50 percentage points. ${ }^{4}$

Table 2: Gross pension replacement rates in 2013 (difference between high and low earners), subset of EU countries

\begin{tabular}{|l|c|c|l|c|c|}
\hline & $\begin{array}{c}\text { Public } \\
\text { schemes }\end{array}$ & Total mandatory & & $\begin{array}{c}\text { Public } \\
\text { schemes }\end{array}$ & Total mandatory \\
\hline Denmark & -50.0 & -56.2 & France & -17.3 & -17.3 \\
\hline Ireland & -48.9 & -48.9 & Portugal & -13.4 & -13.4 \\
\hline Netherlands & -39.4 & -5.0 & Slovak Republic & -10.8 & -10.8 \\
\hline Czech Republic & -37.7 & -37.7 & Finland & -9.4 & -9.4 \\
\hline United Kingdom & -32.7 & -32.7 & Austria & -2.6 & -2.6 \\
\hline Greece & -28.7 & -28.7 & Germany & 0.0 & 0.0 \\
\hline Belgium & -28.0 & -28.0 & Hungary & 0.0 & 0.0 \\
\hline Slovenia & -25.3 & -25.3 & Italy & 0.0 & 0.0 \\
\hline Luxembourg & -24.7 & -24.7 & Poland & 0.0 & 0.0 \\
\hline Sweden & -22.9 & -2.3 & Spain & 0.0 & 0.0 \\
\hline Estonia & -17.4 & -17.4 & EU27 & -17.8 & -16.0 \\
\hline
\end{tabular}

Source: OECD (2013). OECD pension models: difference between replacement rates of two workers making, respectively, $150 \%$ and $50 \%$ of the average worker earnings, in percentage points. Replacement rates are expressed in percentage of individual earnings.

In terms of financing of the public pension system, pay-as-you-go (PAYG) is the most common approach (European Commission, 2015). In a PAYG setting, the mobility of labor entails different effects depending on the direction (emigration vs. immigration), skill composition and size of the migration flow. ${ }^{5}$

\section{Related Literature}

There is an extensive literature analyzing both intergenerational (across generations) and intragenerational redistribution (across income levels). An interesting example of the first is Homburg and Richter (1993), who propose an OLG model in a multi-jurisdiction setting with

${ }^{4}$ Only in two countries, the Netherlands and Sweden, the inclusion of all mandatory schemes significantly reduces the differences between high and low earners. In Denmark, the difference increases. For all the other countries, there is no difference.

${ }^{5}$ The integration of capital markets is particularly interesting in a context where the financing of the systems differs from one country to the other, namely to study the interaction of PAYG and fully funded (FF) schemes. See, for example, Casarico (2000) for competing PAYG and FF systems or Pemberton (2000), for the analysis of the shift from PAYG to FF. Competing PAYG systems may also be studied in a context of integrated capital markets, as in Pemberton (1999). 
integrated markets. Households are homogeneous, ruling out redistribution across income levels, and the PAYG pension scheme is designed with exogenous and time invariant pension contributions (pension benefits adjust passively to ensure the balancing of the system). They conclude that only a centralized pension system is efficiency preserving. Breyer and Kolmar (2002) build on this work, showing that the harmonization of contributions is not only a necessary condition (as shown before by Homburg and Richter, 1993) but also a sufficient one to ensure efficiency. They further extend the model to allow for mobility costs, finding much more restrictive conditions for an efficient allocation of resources.

Cremer and Pestieau (1998) develop a static model of intragenerational redistribution, to study the political economy of social insurance, introducing the so-called Bismarckian factor. The type of social insurance, with Bismarckian and Beveridgean systems at the extremes, is chosen at a constitutional stage (behind the veil of ignorance) and the tax rate to finance the system is then decided through majority voting. They conclude that the type of mobility (poor vs. rich) plays an important role on the tax competition outcome. Furthermore, at the constitutional stage countries adopt more than optimal Bismarckian systems but these systems are not necessarily more tax competition proof. Cremer and Pestieau (2003) study the sustainability of Bismarckian and Beveridgean systems within an economic union when the low-skilled are mobile. They show that, in general, low-skilled move to the Beveridgean country. Only in a setting where the rich in the Bismarckian country do not participate in the system and the Beveridgean country offers no social insurance, it is possible that all poor households move to the Bismarckian country. In both papers, wages are fixed. ${ }^{6}$

Razin and Sadka (2000) and Kolmar (2007), building on the literature of static settings, develop dynamic models thereby combining inter and intragenerational redistribution. They work in a setting with fixed factor prices and exogenously given time invariant tax rates. In the first paper, migration is a one-time episode, of a given fixed amount. With fixed factor prices, the authors show that an in ow of low-skilled workers is beneficial for all skill levels and for young and old households. However, with flexible factor prices, the result does not necessarily hold for the young (through simulations, the authors show that the low-skilled young loose but the young high-skilled, in a large open economy setting and for certain parameters, may still gain). Kolmar (2007) extends the static analysis in Cremer and Pestieau (2003) to a dynamic setting, confirming the main results: under reasonable assumptions and parameters, low-skilled agents move to the Beveridgean country. ${ }^{7}$

With endogenous tax rates, the future pension depends on the unknown future tax rate and thus the households' budget constraint is ill-defined. Boldrin and Rustichini (2000) have shown the rather restrictive conditions needed to guarantee equilibrium in an OLG setting. To circumvent the problem, more applied contributions suppose that the future tax rate is either taken as given by the voters (Tabellini, 2000) or fixed forever (Casamatta et al, 2000b). Conde Ruiz and Profeta (2007), building on Conde Ruiz and Galasso (2003 and 2005) show that the results of the one-time voting can be generalised to a repeated game, with a system of punishment and rewards.

\footnotetext{
${ }^{6}$ For a model without labor mobility, please refer, for instance, to Casamatta et al. (2000a).

7 For models without labor mobility, see, for instance, Conde Ruiz and Profeta (2007) and Casamatta (2000b).
} 
In this paper, we build on the dynamic models developed by Razin and Sadka (2000) and Kolmar (2007) and introduce a voting stage over the tax rate that finances the pension system. Also, we introduce non-myopic voters to this dynamic setting, i.e. voters that take into account the impact of their voting choice on mobility incentives. ${ }^{8}$

With this model we aim at answering two research questions. First, we want to understand the conditions under which the pension systems are politically sustainable and the impact of cross-country low-skilled labor mobility on these voting equilibria. Second, we want to assess the impact of mobility on the welfare of the different agents, allowing us to ascertain the conditions for free low-skilled labor mobility to be politically feasible.

The remainder of the paper is organized as follows. Section 3 presents the model. In Sections 4 and 5 we derive the migration and the voting equilibria and in Section 6 we assess the welfare impact of mobility. Finally, Section 7 concludes.

\section{The Model}

We build an overlapping generations model with two small open economies, integrated in the world capital markets. The countries are symmetric except for the type of public pension system - one is Bismarckian, with pensions related to earnings, and the other is Beveridgean, providing at pensions and performing income redistribution. The national public pension systems are endogeneized, with voters choosing the tax rate that finances it. As in Cremer and Pestieau (2003), low-skilled labor is mobile. ${ }^{9}$ Voters have perfect foresight, in the sense that they incorporate the mobility incentives in their voting decisions.

The timing of our model is as follows: first, agents vote on their preferred tax rate, which is chosen once and forever (as in Casamatta et al, 2000b); then, in the beginning of their working lives, mobile workers move to the country that ensures higher welfare ${ }^{10}$;finally, the young agents of each country work in their country of residence. If a pension system exists, they pay taxes that are used to finance the pensions of the old. The retirement benefit is paid by the country where the individual worked during the first period of life and where she paid her contributions. ${ }^{11}$

${ }^{8}$ For a modelization of non-myopic voters in a static setting, please refer to Cremer and Pestieau (1998) and Epple and Romer (1991).

9 As presented in OECD (2012), low-skilled workers represent, in general, the largest share of foreign-born population in the EU countries.

${ }^{10}$ We assume that agents vote before mobility, in their home country. This is in line with the current setting of the European Union, where voting is mainly linked to citizenship and migrants have limited voting rights. Migrants from other EU-countries are allowed to vote in local and European elections only. Even in the presence of voting rights, e ective participation varies greatly among EU countries. Third-countries migrants (i.e. migrants from outside the EU) have even more restricted voting rights. In addition, the share of migrants acquiring citizenship in the EU (that entitle them to voting rights) is very limited. In 2009, it was less than 3\%, ranging from $0.3 \%$ in Czech Republic to $5.8 \%$ in Portugal (Eurostat, 2011: 247).

11 This is in line with the current framework within the European Union (the residency principle, as opposed to the origin principle). This is also the reason why we can disregard mobility after retirement, since pensions will always be paid by the countries where the household worked. If we think of sources of heterogeneity between countries 


\subsection{The Households}

In each country ( $A$, the Bismarckian, and $B$, the Beveridgean) there are two types of workers, the high (h) and the low-skilled (l). The autarchy ratio of young to old agents (henceforth the autarchy inverse dependency ratio) is given by the constant rate $1+n$. In terms of voting coalitions, our demographic assumptions are that the young outvote the old $(n>0)$ and that the young low-skilled plus the old outvote the young high-skilled. ${ }^{12}$

If the voter is indifferent across tax rates, she decides not to vote (implicitly assuming that there is an infinitesimal cost of casting a vote). Households can also vote with their feet, by moving to the other country in the beginning of their working lives. We assume that, when indifferent, they do not migrate. We follow Cremer and Pestieau (2003) and assume that only low-skilled workers are mobile. ${ }^{13}$

The households live for two periods. When young (period 1) they work (supplying inelastically one unit of labor), contribute to the pension system and save or borrow; when old (period 2) they retire, receive a pension bene t and consume (pay) their savings (loans), plus interest. ${ }^{14}$

The households' lifetime utility is given by: ${ }^{15}$

$$
U_{t}^{i}=\ln c_{t}^{i}+\beta \ln d_{t+1}^{i}, i=h, l
$$

where $c$ and $d$ denote, respectively, consumption in the first and second periods of life and represents the intertemporal discount factor. For tractability reasons, we will assume that $\beta=1$.

The household budget constraints are given by:

$$
\begin{gathered}
c_{t}^{i}=w_{t}^{i}(1-\tau)-s_{t}^{i}, i=h, l \\
d_{t+1}^{i}=s_{t}^{i} R_{t+1}+p_{t+1}^{i}, i=h, l
\end{gathered}
$$

where $w$ represents the wage (there are different wages for the different skill levels), $R$ the market return, $s$ are savings, $\tau$ is the tax rate paid by the young to finance the pension system and $p$ is the pension received upon retirement by the old.

others than the pension schemes (different VAT rates, health system, climate), then the old may as well have incentives to move.

12 These assumptions are in line with Eurostat data: for the EU28, in 2014 the high-skilled, i.e. those with a least tertiary education, represent only $26 \%$ of the working age population (aged 15 to 64); also, there are around 28 people aged 65 or more for each 100 working age agents.

13 Other options may be found in the literature: for example, Cremer and Pestieau (1998) analyze both types of mobility separately in a static framework with fixed wages, while Kolmar (2007) considers mobility of high and low-skilled simultaneously with fixed factor prices and exogenous tax rate.

${ }^{14}$ In order to isolate the effects of pension schemes, distortions coming from the labor-leisure choice are assumed away.

${ }^{15}$ For simplicity of notation we henceforth omit the country index. We will return to the country indexes whenever interpretation is not straightforward. 


\subsection{The Firms}

Firms are perfectly competitive and produce a single homogeneous good according to a common, time invariant constant returns to scale (CRS) production function that uses both capital and labor, $F\left(k_{t}, L_{t}\right)$, respecting the Inada conditions. Labor in each country is measured in efficiency units:

$$
L_{t}=a \mathcal{N}_{t}^{h}+\mathcal{N}_{t}^{l}, a>1,
$$

where a denotes the productivity of the high-skilled (henceforth, the "skill premium"), common to both countries, and $\mathcal{N}_{t}^{l}$ and $\mathcal{N}_{t}^{h}$ represent the low and high-skilled population, respectively. For future reference $\theta_{t}$ represents the ratio of low- to high-skilled agents. In particular, $\theta_{t}^{a}$ stands for the autharchy ratio $\theta_{t}^{m}$ represents the migration equilibrium fraction of low- to high- skilled agents and $\bar{\theta}_{t}^{a}$ reflects the maximum $\theta$, that is, a situation where all low-skilled moved to one country.

Profit maximization implies that marginal productivities match factor prices, namely the internationally given interest rate $R$ and the wage level, $w$. Note that $a w^{l}=w h$. We can omit the time subscript as with two small open economies with CRS, the Capital-Labor ratio K/L remains constant. This also means that mobility has no impact on productive efficiency and we are able to focus solely on redistributive motives for mobility.

\subsection{The Government}

In each country, the government provides pensions to the old households that worked in the country financed by the contributions of the young residents (the so-called Pay-As-You-Go system). Country A is purely Bismarckian, providing earnings related pensions, whereas country B is purely Beveridgean, providing a flat pension, equal across income levels. The pension level that guarantees a balanced government budget (i.e. total contributions in a given period match total pensions paid in that same period) is:

$$
\begin{aligned}
& p_{t+1}^{A, i}=\tau \omega^{i} \frac{L_{t+1}}{L_{t}}, i=h, l \\
& p_{t+1}^{B}=\tau \bar{\omega}_{t+1} \frac{\mathcal{N}_{t+1}}{\mathcal{N}_{t}},
\end{aligned}
$$

where $w$ represents the average wage:

$$
\bar{\omega}_{t+1}=\frac{\mathcal{N}_{t+1}^{h} w^{h}+\mathcal{N}_{t+1}^{l} w^{l}}{\mathcal{N}_{t+1}}=w^{l} \frac{L_{t+1}}{\mathcal{N}_{t+1}}
$$

and $\mathcal{N}_{t}=\mathcal{N}_{t}^{h}+\mathcal{N}_{t}^{l}$. 
The tax rate determines the size of the pension system: the larger the tax rate, the bigger the system. In addition to the tax rate, pensions in both countries increase with the inverse dependency ratio (which is affected by mobility). They are also affected by the wage level: in the Bismarckian country pensions increase with the individual wage level (hence, for the high-skilled, with the skill premium a) while in the Beveridgean country the pension increases with the average wage (which increases with the wage level and the skill premium and decreases the higher the proportion of low-skilled). We implicitly assume that any adjustments to the pension system to ensure its sustainability (i.e. that the system is balanced) are accommodated on the bene $t$ side (the pension level) and not on the contribution side (given that the tax rate is fixed). ${ }^{16}$

Throughout the paper we make the conservative assumption that $R>1+n$. This ensures that, absent redistribution and political economy motives, pension systems would not exist.

\subsection{Voting With Immobile Labor}

As a benchmark, we present the voting decisions when labor is immobile. The motivations of the voters are useful to understand what happens when mobility is introduced.

In order to find the voting equilibrium, we turn to the households maximization problem. In period t, the representative household maximizes lifetime utility (1), subject to the budget constraints (2) and (3) and, also, subject to the pension offered in her country, (5) or (6). As stated before, voters are non-myopic in the sense that they take into account migration incentives in their voting decisions.

When labor is not mobile, $\mathcal{N}_{t+1} / \mathcal{N} t$ and $L_{t+1} / L t$ are both equal to the inverse autarchy ratio of young to old agents $(1+n)$, the autarchy dependency ratio. Old agents always favor the largest possible system as they are not subject to the pension contribution tax.

Turning to the young generation, it is immediate that having a pension system is never a good deal, except if redistribution across incomes compensates the returns differential. This can only happen for low-skilled in the Beveridgean country when:

$$
\frac{\bar{\omega}_{t+1}}{\omega^{i}}(1+n)>R
$$

which can be re-written as:

$$
R<(1+n) \frac{a+\theta_{t+1}^{a}}{1+\theta_{t+1}^{a}},
$$

16 An alternative to formulation (5), which still ensures a balanced government budget, is to consider that the different types of workers (high- and low-skilled) contribute to separate systems: $p_{t+1}^{A, i}=\tau \omega^{i} \frac{\mathcal{N}_{t+1}^{i}}{\mathcal{N}_{t}^{i}}, i=l, h(8)$. This does not seem to be the case in most systems and, thus, we focus on the formulation given by (5). 


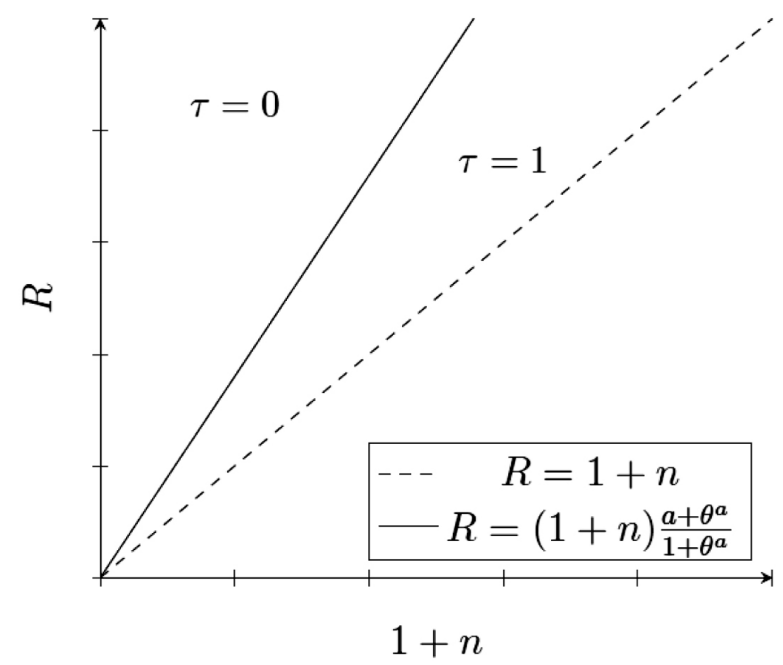

where $\theta_{t+1}^{a}$ represents the autharchy ration of low to high-skilled agents. Figure 1 displays the voting decisions of young low-skilled in the Beveridgean country. The higher the skill premium and the lower the ratio of low- to high-skilled households, the more likely it is for the young low-skilled to support the system (the solid black line rotates to the left). This happens because the gains from redistribution also increase.

Condition (10) is sufficient to ensure a pension system in the Beveridgean country: the young high-skilled, that vote against the system, are outvoted by the young low-skilled plus the old.

In a nutshell, in the absence of labor mobility, the Bismarckian country never provides pensions. The Beveridgean country has a pension system if and only if the gains from income redistribution for the young low-skilled are sufficiently high.

For future reference, let us discuss which country better suits the different agents. First, note that if there are no pension systems, the countries are equal in all respects and thus the utility of each agent type is the same across countries. If the Beveridgean offers a pension system, then the old are better-o in that country as they see their utility increased. For the young, it depends on their net contribution to income redistribution: the young low-skilled fare better in the Beveridgean whereas young high-skilled have higher utility in the Bismarckian. 


\section{Mobility Equilibrium}

We now consider that the low-skilled can freely move between the two countries. It turns out that, when the Beveridgean adopts a pension system, the low-skilled may migrate to the Bismarckian country (if the Beveridgean does not offer a pension system, there is no mobility as there is no system in either country). This is summarized in Proposition 1.

Proposition 1 (Mobility equilibrium when the Beveridgean offers a pension system - exogenous pension size). Consider two small open economies, a Bismarckian and a Beveridgean country. When the size of the pension system is exogenous, low-skilled may flow in either direction. There is migration from the Beveridgean to the Bismarckian when income redistribution is too low to compensate for the low market returns, that is, $R>(1+n) \frac{a+\theta^{a}}{1+\theta^{a}}$.

The mobility equilibria are presented in Figure 2. ${ }^{17}$

The mobility equilibrium depends on four parameters: the skill premium, a, that, together with the ratio of low- to high-skilled agents, determines the degree of redistribution across income levels; the inverse autarchy dependency ratio, $1+n$, that determines the redistribution across generations. Note that the higher or lower number of contributors to the system due to mobility only affects the current generation of pensioners; by the time the current young retire, the dependency ratio is back to its natural level. And, finally, the international interest rate $(R)$ that represents the returns on market investments.

Figure 2: Mobility equilibria, direction and size of migration of low-skilled young when the Beveridgean offers a pension system

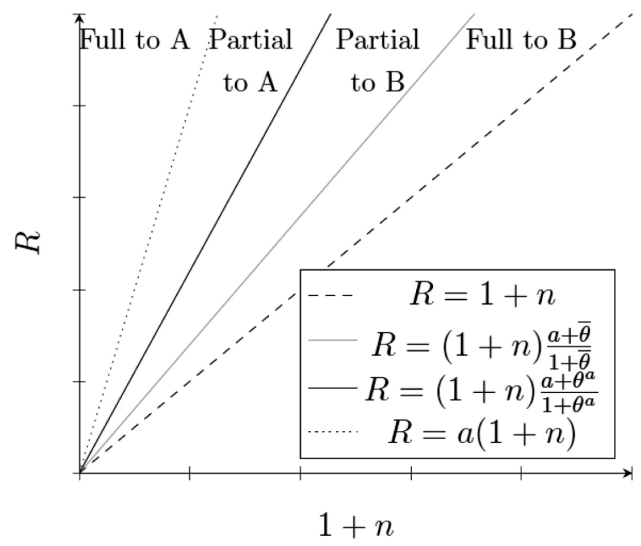

${ }^{17}$ Note that the number of low-skilled cannot be negative (zero is the lower-bound, which implies that all young low-skilled moved out of the country) nor can migration exceed the sum of the total number of agents of that skill-type in the two countries (which occurs when all low-skilled move to the country). These conditions imply that $0 \leq \frac{R-a(1+n)}{1+n-R} \leq^{-} \theta^{B}$, where $\theta^{B}=\frac{\mathcal{N}^{A+B, l}}{\mathcal{N}^{B, h}}$ 
As we show next, if the Beveridgean country offers a pension system, then the young low-skilled move to the Bismarckian country as long as income redistribution is too low to compensate for the low market returns. Conversely, for sufficiently high income redistribution compensating for the lower market returns, the young agents move to the Beveridgean country. When redistribution is sufficiently high (respectively, low), all low-skilled live in the Beveridgean country (respectively, Bismarckian country).

To arrive to these results, we have to first assess what happens in the Bismarckian country, where the voting decision of the young is not affected by mobility. In fact, the way mobility affects the young agents is through its effect on the average wage. In that country, the average wage does not play any role and, therefore, for young agents the preferred tax rate is $\tau=0 .{ }^{18}$ For old agents, the preferred tax rate depends on mobility, which determined the number of contributors to the system. However, as long as there is no full migration to the Beveridgean country, the young still form a majority and there is no pension system in the Bismarckian. The exception is when all the young low-skilled of the Bismarckian move to the Beveridgean - we discuss this case later. ${ }^{19}$

For the moment, let us focus on the case where the Bismarckian country does not have a pension system and find the equilibria in the Beveridgean country. A mobile agent compares the utility she may get in the two countries. In the Bismarckian country, utility is given by:

$$
U_{t}^{A, l}=\ln \left(w^{l} \frac{1}{2}\right)+\ln \left(w^{l} R \frac{1}{2}\right),
$$

where we have used the optimal saving decision.

Utility in the Beveridgean country can be written as:

$$
U_{t}^{B, l}=\ln \left(w^{l}\left(1-\tau^{B}\right)-S_{t}^{B, l}+\ln \left(S_{t}^{B, l} R+\tau^{B} \bar{\omega}_{t}(1+n),\right.\right.
$$

where, from the first order conditions of the household maximization problem, savings are given by:

$$
S_{t}^{B, l}=w^{l} \frac{\left[R\left(1-\tau^{B}\right)-\tau^{B} \frac{L_{t}^{B}}{\mathcal{N}_{t}^{B}}(1+n)\right]}{2 R} .
$$

If the pre-mobility utility in the Bismarckian is larger (smaller) than in the Beveridgean, then low-skilled agents move to the Bismarckian (Beveridgean). In equilibrium, utilities in both countries are equalized, unless all low-skilled agents locate in one of the countries.

\footnotetext{
18 We recall that $R>(1+n)$.

19 These mobile workers are indifferent about the tax rate of their origin country and thus do not cast a vote. In this context, the majority coalitions may change. Whenever this is true, we discuss the conditions for a new equilibrium in the Bismarckian country.
} 
An interior migration equilibrium is given by the equalization of utility levels as given by (11) and (12):

$$
\mathcal{N}_{t}^{B, l}=\mathcal{N}_{t}^{B, h}\left(\frac{R-a(1+n)}{1+n-R}\right)
$$

or

$$
\theta_{t}^{B, m}=\frac{R-a(1+n)}{1+n-R}
$$

where $\theta^{m}$ represents the equilibrium fraction of low- to high- skilled agents. Expressions (14) and (15) define an interior equilibrium, which arises when:

$$
R \in(1+n) \frac{a+\bar{\theta}}{1+\bar{\theta}},(1+n)
$$

If $R$ is below the lower bound, all low-skilled move to the Beveridgean country. If $R$ exceeds the upper bound then all low-skilled migrate to the Bismarckian.

\section{Voting EQUILIBRIUM}

In this section we show that three voting scenarios may arise when labor is mobile: no pension system in either country; a pension system only in the Beveridgean; or a pension system in both countries, the latter an outcome which was not possible in the no mobility case. These results are summarized in Proposition 2.

Proposition 2 (Impact of mobility on voting). Consider two small open economies, a Bismarckian and a Beveridgean country, with endogenous tax rates and non-myopic voters. Mobility changes the size of the pension system. In particular, whenever $R<(1+n) \frac{a+\bar{\theta}}{1+\bar{\theta}}$ and the old outvote the young high-skilled, mobility allows for the creation of a pension system in the Bismarckian country (which would not exist with immobile labor); whenever $R<(1+n) \frac{a+\bar{\theta}}{1+\bar{\theta}}<R<(1+n) \frac{a+\theta^{a}}{1+\theta^{a}}$ and the young high-skilled outvote the old, mobility implies that there is no pension system in the Beveridgean country (which would exist with immobile labor). This result holds even though, under these conditions, no mobility occurs in equilibrium.

For the Bismarckian country, only with labor mobility can a pension system exist. In the Beveridgean country, labor mobility makes the conditions for the existence of the system (weakly) more stringent. It is interesting to note that mobility may have an impact on the 
existence of the pension system even for those cases where households choose not to migrate. Under the conditions of Proposition 2, the tax rate in the Beveridgean country changes from $\tau=1$ to $\tau=0$ because the threat of an in ow of low-skilled from the Bismarckian to the Beveridgean in case of $\tau>0$ makes the young low-skilled of the Beveridgean indifferent across all possible tax rates (as $\tau=0$ ) with no mobility provides them the same utility as any other $\tau>0$ with in ow mobility) and thus they have no incentive to cast a vote.

The results of the mobility equilibrium with endogenous pension size are summarized in Proposition 3 and can be directly derived from Proposition 1 together with the outcome of the voting equilibrium discussed above.

Proposition 3 (Mobility equilibrium with endogenous pension size). Consider two small open economies, a Bismarckian and a Beveridgean country, with endogenous tax rates and non-myopic voters. If $R$ is suficiently high, $R>(1+n) \frac{a+\theta^{a}}{1+\theta^{a}}$, there is no pension system in the Beveridgean country and no mobility occurs. If is not sufficiently high, low-skilled move to the Beveridgean country.

To arrive to the conclusions presented in Proposition 3, we first determine the voting equilibria in the Beveridgean country using (14) and the results of the mobility analysis of the previous subsection. Note that mobility does not depend on the tax rate - as long as it is positive, the incentives to move depend solely on the possible gains from income redistribution. Thus, old agents vote for the maximum tax rate $(\tau=1)$ and young high-skilled agents vote for no pension system $(\tau=0)$, as they do in closed economy. For the low-skilled, there are three possible outcomes (summarized in Figure 3).

When low-skilled agents have an incentive to move to the Bismarckian country if the tax rate in their home country is positive, they always prefer to stay and vote for $\tau=0$. This yields the same final utility as if they would move. Thus, there is no pension system in the Beveridgean country, as the young outvote the old.

If the migration equilibrium is interior with in ow into the Beveridgean, the young low-skilled of the Beveridgean are indifferent amongst tax rates in their country since they are not affected by it (their final utility is the utility of the other country, which does not change with mobility) and thus they have no incentive to cast their vote. The voting outcome depends on the relative number of young high-skilled and old: if the young high-skilled outvote the old there is no pension system; otherwise, it is $\tau=1$.

Finally, if the migration equilibrium is a corner solution with full migration to the Beveridgean country, young low-skilled agents of the Beveridgean are not indifferent between tax rates as they stay in their home country. This happens when redistribution is sufficiently high; hence, they vote for $\tau=1$. There is then full mobility from the Bismarckian to the Beveridgean country. Young low-skilled from the Bismarckian do not vote, as they get the utility of the other country. In that case, the voting equilibria in the Bismarckian country remains unchanged (i.e. no pension system) if and only if the young high-skilled of that country outvote the old. If, conversely, the old outvote the young high-skilled, then the tax rate $\tau=1$ constitutes the new equilibrium in the country. Do the young low-skilled agents still want to move to the Beveridgean, in case the Bismarckian offers a pension system? The answer 
is yes - if they would all move in their best case scenario (i.e. a tax rate equal to zero), the result is only reinforced with the new tax rate. In the Beveridgean country, this new voting equilibrium has no impact as the only thing that matters is that all young low-skilled move to the country if there is a pension system in the Beveridgean (and the final utility is higher than in the other country). Given that those in favor of the system form a majority (young low-skilled plus the old), the voting outcome in the Beveridgean is $\tau=1$ (and there is full mobility to the Beveridgean).

Figure 2 can now be updated with the voting results discussed above. As summarized in Figure 4, a pension system never exists in the Beveridgean country when the return of the market is sufficiently high $R>(1+n) \frac{a+\theta^{a}}{1+\theta^{a}}$ and, therefere, no mobility takes place. End geneizing the pension system thus implies that whenever mobility occurs the flow goes from the Bismarckian to the Beveridgean country.

Putting together the results of Propositions 2 and 3, one sees that even when there is no mobility in equilibrium, the pension system may no longer be feasible in the Beveridgean country. In addition, in the Bismarckian country, a pension system can only exist if the country becomes older, by having all the mobile young leaving to the Beveridgean.

Figure 3: Voting of the young low-skilled in the Beveridgean country with labor mobility

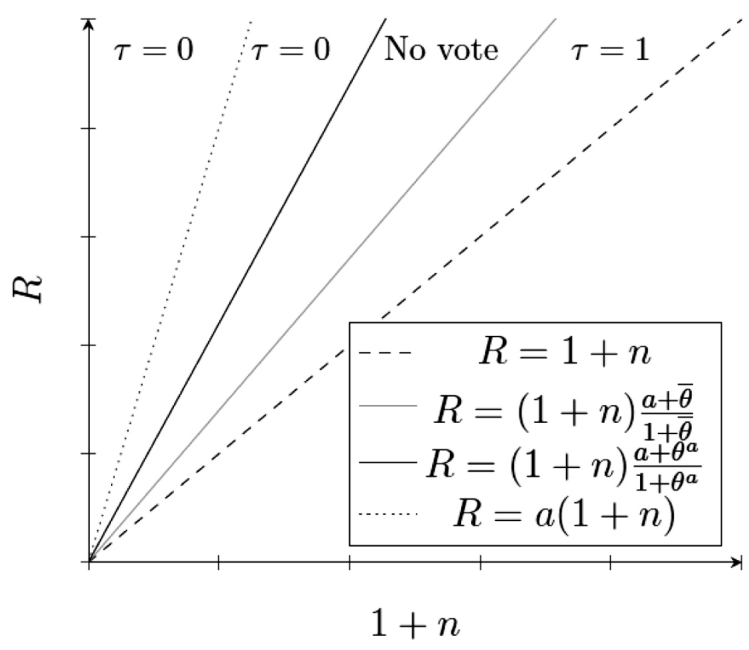


Figure 4: Mobility equilibria with endogenous pension size and the Beveridgean offers a pension system: direction and size of migration of low-skilled young

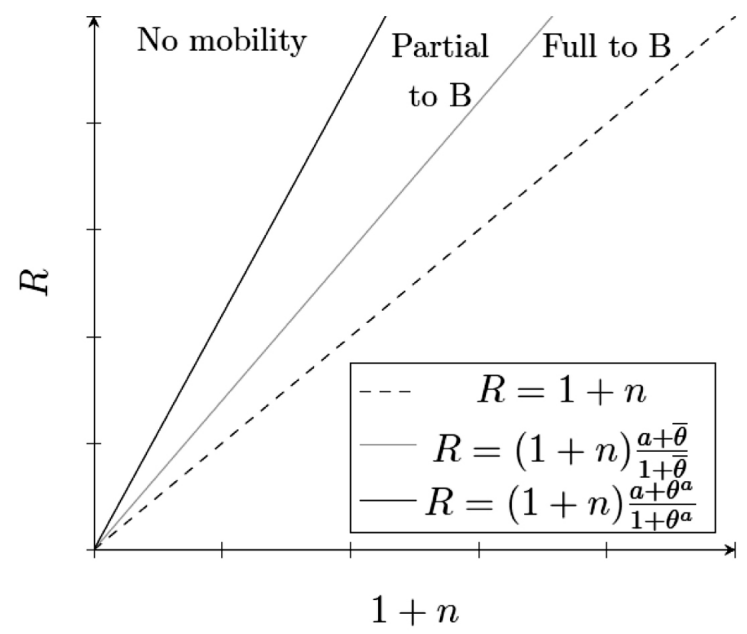

\section{Welfare Analysis}

Finally, we assess the welfare associated with the different voting and mobility equilibria studied above.

\subsection{Whigh Gountry Better Suits The Different Agents?}

We start with a comparison of the level of welfare obtained by the different types of agents. Are the agents of one country better-o than the agents of the other country?

Mobility ensures that all the young low-skilled agents enjoy the same utility.20 The interesting question relates to the relative welfare of the young high-skilled and the old. Table 3 summarizes the results.

Without a pension system in the two countries, the utility levels are equal across countries. If only the Beveridgean adopts a pension system, the young high-skilled of that country are always worse-o than their counterparts in the Bismarckian country that do not have to pay for income redistribution. Concerning old agents, the old of the country with pensions

20 This happens because they either all locate in the same country or they get the same utility in both countries, the latter because they equalize cross-country utility levels by moving or because neither country offers a pension system. 
are better-o than the ones in the country that does not provide pensions, where they get no old-age benefit.

If the two countries adopt a pension system, there is full mobility to the Beveridgean. As before, the young high-skilled are better-off in the Bismarckian country, without income redistribution. Conversely, the old low-skilled of the Beveridgean are better-o than their counterparts in the Bismarckian as they have a pension based on the average wage (and not on their type wage) and have more contributors to the system (all low-skilled moved to the Beveridgean). Finally, the comparison between the utility of an old high-skilled depends on the trade-o between number of contributors and pensionable wage - for a large enough skill premium, the pensionable wage effect dominates; if the skill premium is not large enough, the number of contributors effect dominates.

\subsection{Political Feasibility Of Cross-Country Labor Mobility}

Finally, we assess the impact of labor mobility on the welfare of the natives of the different countries: who are the winners and the losers of opening the borders to low-skilled labor? The goal in this section is to understand the conditions for mobility to be politically feasible, i.e. when a majority of agents is not harmed with the low-skilled worker flows (as it would undermine the necessary political support). The question of the impact of low-skilled migration has been widely debated in the context of the EU, with some countries assessing the possibility of closing their borders to other EU countries or at least to increase migration restrictions.

Our results are summarized in Proposition 4.

Proposition 4 (Impact of mobility on welfare). Consider two small open economies, a Bismarckian and a Beveridgean country, with endogenous tax rates and non-myopic voters. Then, whenever $R<(1+n) \frac{a+\theta^{a}}{1+\theta^{a}}$, here is always a majority in the Beveridgean country against cross-country low-skilled labor mobility. In the Bismarckian country there is never a majority against cross country low-skilled labor mobility. Furthermore, whenever $R<(1+n) \frac{a+\bar{\theta}}{1+\bar{\theta}}$ those benefited from mobility outvote those against it.

For young agents, mobility affects two critical factors. The first is the size of the relevant pension system. The relevant pension system is the home country for those that do not move and the host country for those that move. The tax rate to which the agents are subject may change because the agents move to a country with a different tax rate but also because mobility changes the voting equilibrium. The second factor is the pensionable wage of the Beveridgean country. In that country, the pensionable wage is the average wage, which depends on the relative number of low- and high-skilled agents working in the country.

For old agents, in addition to the two factors already mentioned for the young population, there is a third critical factor, namely the ow of migrants, which impacts the ratio of 
contributors to beneficiaries. This is irrelevant for the young, as migration occurs when they are young; their children are the ones who pay for their pensions and thus all that matters for them in this respect is the natural inverse dependency ratio, $1+n$.

Table 4 summarizes the results. In a nutshell, cross-country low-skilled labor mobility is always politically feasible in the Bismarckian country as there is never a majority of native harmed with mobility. Only when the interest rate is sufficiently low, there is a welfare impact for some groups of agents and this impact is, in general, positive. The only exception occurs when the old outvote the young high-skilled and a pension system emerges in the country, harming the young high-skilled (which nevertheless do not form a majority). This implies that, in the Bismarckian country, not only there is never a majority harmed with mobility but, when $\mathrm{R}$ is sufficiently low, those that bene t from mobility outvote those that are harmed by it.

In the Beveridgean country, except for the cases where the interest rate is sufficiently large (and thus the voting equilibrium of the immobile labor setting with no pension system in both countries is sustained), there is always a welfare impact for the different groups of agents. For the cases where there is an in ow from the Bismarckian country, old agents are better-o while young agents see their welfare being reduced. But, as explained before, for mobility to have an impact on the pension systems and on welfare, it does not necessarily have to occur. Even for those cases where there are no incentives for labor to move, free labor mobility may have welfare consequences if it brings the tax rate in the Beveridgean country to zero. This is harmful for all agents except the young high-skilled (that nevertheless do not form a majority), which are better-o without the system. ${ }^{21}$

One can then conclude that, in the Beveridgean country, cross-country low-skilled labor mobility is harmful for a majority of the population if $\mathrm{R}$ is not sufficiently large, implying that there is an in ow of low-skilled to the country or that the existence of the system in the country is jeopardized, going from a positive tax rate to a zero tax rate. Under these conditions, labor mobility can only be politically feasible if appropriate compensatory measures are devised.

21 Recall that the change from $\tau=1$ to $\tau=0$ happens because the threat of an in ow of low-skilled from the Bismarckian to the Beveridgean in case of $\tau>0$ makes the young low-skilled of the Beveridgean indifferent across all possible tax rates (as $\tau=0$ ) with no mobility provides them the same utility as any other $\tau>0$ with in ow mobility) and thus they have no incentive to cast a vote. 


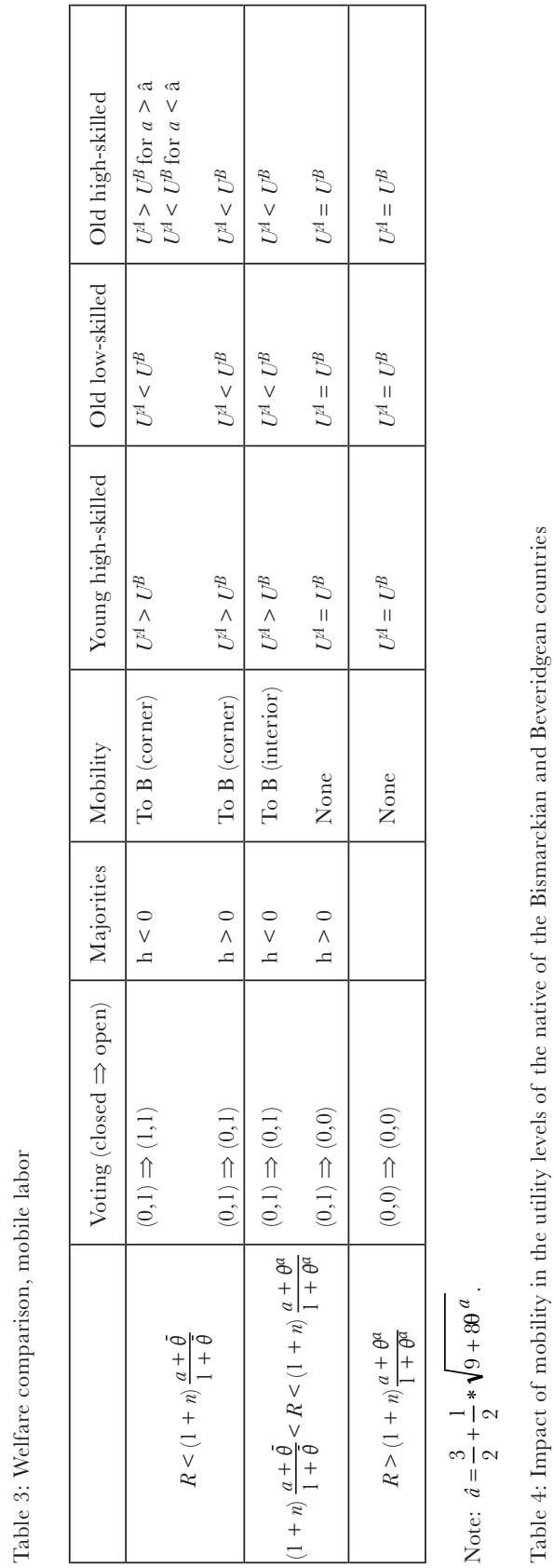

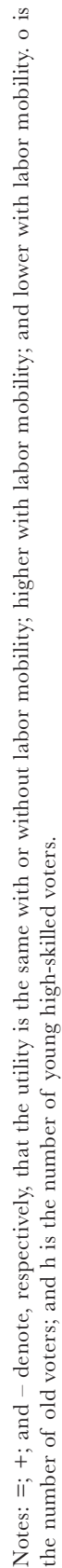




\section{Goncluding Remarks}

We assess the consequences of decentralized asymmetric pension systems in a context of partial labor mobility. We show the conditions for a pension system to arise, as a function of the market returns and of inter- and intragenerational redistribution and, also, of the structure of the population (skill level and age). With non-myopic voters, the voting equilibrium may change with the possibility of mobility: in fact, the system may be created in the Bismarckian country, as the ageing of the population caused by the departure of the young mobile may create a majority in favor of pensions. Also, the pension system may be eliminated in the Beveridgean country, as the conditions for its existence become more stringent. In this case, it is interesting to note that mobility changes the voting equilibrium even though no migration actually occurs.

In the cases where at least one of the countries adopts a pension system, young low-skilled workers migrate to the most generous country (i.e. the country with higher income redistribution) but we do not necessarily have a corner solution, with all low-skilled young in the Beveridgean. This only happens if the potential gains from income redistribution are sufficiently high.

When the interest rate is sufficiently low, the Beveridgean (but not the Bismarckian) has a majority harmed by mobility. Thus, labor mobility can only be politically sustainable if appropriate compensatory measures are devised.

Some of our assumptions are important for the results achieved. We assume that the intergenerational redistribution is (contrary to the intragenerational redistribution) equal in both countries, since the autarchy dependency ratio is the same. Also, this autarchy dependency ratio is equal for low and high-skilled agents. The introduction of asymmetric natural growth rates across countries and across skill types would lead to more intricate incentives concerning voting and mobility decisions. Another important assumption concerns the production technology. The substitutability between both types of labor, low and high-skilled, has important welfare implications due to the positive relation between the wage levels. The type of mobility is also relevant to the results since, in our setting, only the agents that benefit from intragenerational redistribution are allowed to migrate. We could also explore the possibility of compensations across agents and/or countries.

\section{REFERENGES}

Altonji, J.; Card, D. (1991) The effects of immigration on the labor market outcomes of less-skilled natives, NBER Chapters in Immigration, Trade and the Labor Market, 201-234.

Boldrin, M.; Rustichini, A. (2000) Political equilibria with social security, Review of Economic Dynamics, $3,41-7$

Breyer, F.; Kolmar, M. (2002) Are national pension systems efficient if labor is (im)perfectly mobile? Fournal of Public Economics, 83, 347-374.

Calabrese, S.; Epple, D.; Romer, T.; Sieg, H. (2006) Local public good provision: Voting, peer effects, and mobility, Fournal of Public Economics, 90 (6-7), 959-981. 
Casarico, A. (2000) Pension systems in integrated capital markers, Topics in Economic Analysis and Policy, 1, 1-17.

Casamatta, G.; Cremer, H.; Pestieau, P. (2000a) Political sustainability and the design of social insurance, Fournal of Public Economics, 75, 341-364.

Casamatta, G.; Cremer, H.; Pestieau, P. (2000b) The political economy of social security, CESifo Working paper series, Working Paper 259.

Conde Ruiz, J.; Galasso, V. (2003) Early retirement, Review of Economic Dynamics, 6(1), 12-36.

Conde Ruiz, J.; Galasso, V. (2005) Positive arithmetic of the welfare state, fournal of Public Economics, 89 (5-6), 933-955.

Conde Ruiz, J.; Profeta, P. (2007) The redistributive design of social security systems, Economic fournal, 117, 686-712.

Cousins, M. (2005) European Welfare States: Comparative Perspectives, London, Sage Publications.

Cremer, H.; Pestieau, P. (1998) Social insurance, majority voting and labor mobility, Fournal of Public Economics, 68, 397-420.

Cremer, H.; Pestieau, P. (2003) Social insurance competition between Bismarck and Beveridge, fournal of Urban Economics, 54, 181-196.

Dominitz, J.; Manski, C.; Heinz, J. (2003) Will social security be there for you? How Americans perceive their benefits, NBER Working Paper No. 9798.

Epple, D.; Filimon, R.; Romer, T. (1984) Equilibrium among local jurisdictions: Toward an integrated treatment of voting and residential choice, Fournal of Public Economics, 24 (3), 281-308.

Epple, D.; Romer, T. (1991) Mobility and redistribution, Fournal of Political Economy, 99 (4), 828-858.

European Commission (2015) 2015 Ageing report: Economic and budgetary projections for the EU-28 Member States (2013-2060), European Economy, 3.

European Commission (2013) EU employment and social situation - Quarterly review: Special supplement on demographic trends.

Eurostat (2011) Indicators of immigrant integration: A pilot study, Population and Social Conditions, Eurostat Methodologies and Working Papers, Publications Office of the European Union.

Feldstein, M.; Liebman, J. (2002) Social Security, in A.J. Auerbach and M. Feldstein, Handbook of Public Economics, Vol. 4, Ch. 32, Amsterdam: Elsevier.

Giorgi, G.; Pellizzarib, M. (2009) Welfare migration in Europe, Labour Economics, 16 (4), 353-363.

Homburg, S.; Richter, W. (1993) Harmonizing public debt and pension schemes in the European Community, Fournal of Economics, 7, 51-63.

Kolmar, M. (2007) Beveridge versus Bismarck public-pension systems in integrated markets, Regional Science and Urban Economics, 37 (6), 649-669.

Meyer, B. (2000) Do the Poor Move to Receive Higher Welfare Benefits? Working paper 58, Northwestern University, Joint Center for Poverty Research.

OECD (2012) International migration outlook, OECD publishing.

OECD (2013) Pensions at a Glance 2013: Retirement-Income Systems in OECD and G20 Countries, OECD Publishing.

Pemberton, J. (1999) Social security: National policies with international implications, Economic fournal, 109, 492-598.

Pemberton, J. (2000) National and international privatisation of pensions, European Economic Reviere, 44, 1873-1896. 
Pierluigi, B.; Moreno Roma, M. (2008) Labour cost and employment across euro area countries and sectors, Working Paper Series 912, European Central Bank.

Razin, A.; Sadka, E. (2000) Unskilled migration: A burden or a boon for the welfare state? Scandinavian Fournal of Economics, 102 (3), 463-479.

Tabelinni, G. (2000) A positive theory of social security, Scandinavian Fournal of Economics, 102 (3), 523-45 .

Wildasin, D. (1999) Public pensions in the EU: Migration incentives and impacts, in A. Panagariya, P.R. Portney, and R.M. Schwab (Eds.), Environmental Economics and Public Policy: Essays in Honor of Wallace E. Oates, Cheltenham, Edward Elgar. 